\title{
Pengembangan Media Pembelajaran Faktorisasi Prima Berbasis Android di Kelas IV Sekolah Dasar
}

\author{
Suwandi ${ }^{1)}$, Sri Utaminingsih ${ }^{2)}$, Eko Darmanto ${ }^{3)}$ \\ Magister Pendidikan Dasar, Universitas Muria Kudus, Indonesia ${ }^{1), 2), 3)}$ \\ Email korespondensi : cakrademak@gmail.com ${ }^{1)}$
}

\begin{abstract}
Abstrak.Tujuan dari penelitian ini adalah mengembangkan media pembelajaran faktorisasi prima berbasis android serta menguji keefektifannya. Penelitian ini pendekatan penelitian dan pengembangan (Research and Development). Prosedur penelitian dan pengembangan mengacu pada model pengembangan Borg \& Gall yang dikombinasikan dengan metode Software Development Life Cycle. Teknik pengumpulan data menggunakan observasi, angket, wawancara, dokumentasi dan tes. Sedangkan teknik analisis data menggunakan analisis deskriptif kualitatif dan kuantitatif. Hasil penelitian media pembelajaran yang dikembangkan adalah media pembelajaran faktorisasi prima berbasis android dengan tampilan berupa visual, gambar, suara dan video. Tampilan dalam media faktorisasi prima berbasis android adalah ikon, pembuka / layar utama, materi, penjelas, latihan dan ulangan.
\end{abstract}

Kata kunci: media pembelajaran, android, faktorisasi prima

\begin{abstract}
The aim of this research is to develop Android-based prime factorization learning media. This research is a research and development approach (Research and Development). The research and development procedure refers to the Borg \& Gall development model combined with Software Development Life Cycle methods. Data collection techniques using observation, questionnaires, interviews, documentation and tests. While the data analysis technique used qualitative and quantitative descriptive analysis. The results of the study of learning media developed were andrid-based prime factorization learning media with visuals, images, sounds and videos. The displays in the Android-based prime factorization media are ikon, opening / main screen, material, explanations, exercises and tests.
\end{abstract}

Keywords::learning media, android, prime factorization 


\section{PENDAHULUAN}

Penyebaran virus corona pada awalnya sangat berdampak pada dunia ekonomi dan sosial, tetapi kini dampaknya dirasakan juga oleh dunia pendidikan (Purwanto, et al., 2020). Pandemi Covid-19 telah mempengaruhi semua sistem pendidikan dari tingkat pra-sekolah, sekolah dasar, sekolah menengah hingga lembaga perguruan tinggi. Penutupan lembaga pendidikan pra sekolah, pendidikan dasar sampai jenjang perguruan tinggi akibat pandemi Covid-19 memiliki pengaruh yang besar dalam proses pembelajaran dan kurikulum pendidikan (Rahmawati \& Putri, 2020). Akibat situasi pandemi Covid-19, pemerintah Indonesia menerapkan physical distancing bagi warga negara. Physical distancing yang harus diterapkan menyebabkan proses pembelajaran peserta didik dalam kelas harus dirubah metodenya dengan learning from home atau belajar dari rumah (Herliandry, et al., 2020). Namun demikian, Pembelajaran jarak jauh harus inklusif, menghargai perbedaan setiap wilayah, memastikan tindakan untuk meningkatkan kualitas pendidikan dan penghapusan hambatan jarak agar pembelajaran lebih efektif (Camacho, et al, 2020).

Salah satu pelajaran daring yang penting untuk dipelajari adalah matematika. Matematika menjadi penting untuk dipelajari di tingkat sekolah karena matematika adalah ilmu dasar yang memberikan kontribusi besar dan berperan penting dalam perkembangan ilmu pengetahuan dan teknologi. Matematika merupakan ilmu universal yang mendasari perkembangan teknologi modern, mempunyai peran penting dalam berbagai disiplin dan mengembangkan daya pikir manusia. Dalam materi kelas 4, siswa diharapkan memiliki kemampuan untuk dapat menentukan faktorisasi prima dan menyelesaikan masalah faktorisasi prima. Salah satu cara yang dapat digunakan adalah dengan menggunakan hasil pohon faktor.

Hasil wawancara peneliti dengan guru kelas 4 SDN Balerejo 2 Kecamatan Dempet Kabupaten Demak, menunjukkan bahwa sebagian besar siswa mengalami kesulitan dalam menentukan faktorisasi prima serta penyelesaiannya. Hal tersebut disebabkan karena metode mengajar guru yang belum optimal dan pelaksanaan pembelajaran tidak menggunakan media pembelajaran. Pembelajaran menggunakan sistem daring menyebabkan siswa harus belajar memahami materi sendiri sehingga 
siswa kurang tertarik dengan pelajaran yang menyebabkan siswa bosan dalam proses pembelajaran.

Inovasi pembelajaran dampak Covid-19 sebenarnya membuka paradigma baru bagi lembaga pendidikan yang tidak lagi menggambarkan proses pembelajaran harus melalui tatap muka di dalam kelas (Fitriyani, et al., 2020). Ada peran penting sistem informasi teknologi jarak jauh dengan daring (online) dalam pendidikan yang harus disiapkan untuk menjalankan metode learning from home. Salah satu alternatifnya dengan memanfaatkan android sebagai media pembelajaran.

Media yang digunakan guru dalam pembelajaran daring masih kurang optimal, sehingga dibutuhkan media pembelajaran yang lebih inovatif dan interaktif agar pembelajaran lebih efektif dan efisien. Perkembangan dunia digital yang sangat pesat menuntut guru untuk dapat beradaptasi terutama dalam proses pembelajaran. Nunuk (2018:9) menyatakan penggunaan media visual dan komunikasi verbal lebih meningkatkan daya ingat siswa dibandingkan menggunakan komunikasi verbal atau visual saja. sedangkan Azhar (2019:29) berpendapat bahwa penggunaan media pembelajaran dapat meningkatkan dan mengarahkan perhatian anak sehingga dapat menimbulkan motivasi belajar dan memungkinkan siswa untuk belajar sendiri sesuai dengan kemampuan dan minatnya.

Berkaitan dengan permasalahan tersebut, perlu dilakukan pembenahan, penyesuaian, dan pembaruan dalam kegiatan pembelajaran pada masa pandemi Covid-19, yakni dengan mengembangkan dan memanfaatkan media pembelajaran berbasis android yang dapat menampilkan konsep-konsep yang abstrak dan mikroskopis yang sulit divisualisasikan atau ditampilkan secara langsung di laboratorium. Secara umum android banyak digunakan oleh masyarakat khususnya peserta didik

Android merupakan operasi sistem mobile yang memodivikasi dari linux. Awalmulanya dikembangkan startup dengan nama yang sama yaitu Android inc. Pada tahun 2005 google melihat banyaknya pengguna yang online menggunakan perangkat mobile dan melihat masa depan yang cerah untuk dunia mobile sehingga pada tahun itu lah google membeli Android dan mengambil alih perkembangannya (Lee, 2011: 2) 
Pengembangan media berbasis android diharapkan agar literasi peserta didik dapat meningkat. Pembelajaran dengan menggunakan media pembelajaran memungkinkan peserta didik untuk fokus pada konten. Media pembelajaran memuat unsur-unsur media secara lengkap yang meliputi audio animasi, video, teks, dan grafis yang memungkinkan pengguna untuk berinteraksi secara interaktif melalui fitur-fitur yang tersedia (Gunawan, et al., 2017).

Batubara, H. H. (2018). Pengembangan media pembelajaran matematika berbasis android untuk siswa SD/MI. Hasil penelitian 1) Peneliti telah menghasilkan media pembelajaran matematika berbasis android pada materi bangun datar untuk siswa kelas IV SD/MI, 2) Penilaian ahli, peer reviewer dan guru sekolah dasar terhadap produk mendapat skor 434 dan persentase 86,67\%, sangat baik, 3) tanggapan siswa kelas IV SD/ MI terhadap media pembelajaran matematika berbasis android memperoleh skor 439 dengan persentase penilaian 87,8\%. Nilai tersebut berada pada interval antara setuju dan sangat setuju

Zakiy, M. A., Syazali, M., \& Farida, F. (2018). Pengembangan Media Android dalam Pembelajaran Matematika. Penelitian ini menghasilkan sebuah media pembelajaran matematika berbasis android yang telah dinyatakan valid dan layak digunakan sebagai media pembelajaran matematika oleh 3 orang ahli materi yang memperoleh skor rata - rata 3,67 (Layak) dan 2 orang ahli media dengan perolehan skor rata - rata 3,59 (Layak) dengan masing - masing skor maksimal kelayakan adalah 4. Dari hasil tersebutdapat disimpulkan bahwa media pembelajaran matematika berbasis androidmemiliki sejumlah pengetahuan, sikap dan keterampilan sebagai hasil belajar. Dari hal diatas, peneliti tertarik untuk mengembangkan media pembelajaran faktorisasi prima berbasis android yang lebih menarik, inovatif, interaktif agar pembelajaran lebih efektif dan efisien.

\section{METODE PENELITIAN}

Penelitian Pengembangan media pembelajaran faktorisasi prima berbasis android untuk meningkatkan hasil belajar siswa kelas IV materi faktorisasi prima merupakan penelitian yang menggunakan pendekatan penelitian dan pengembangan (Research and Development) yang dikombinasikan dengan metode pengembangan 
perangkat lunak SDLC. Prosedur penelitian dan pengembangan mengacu pada model pengembangan Borg \& Gall yang terdiri atas 10 langkah yang disederhanakan menjadi 5 langkah sebagai berikut: (1) penelitian dan pengumpulan data awal; (2) perencanaan produk; (3) pengembangan format produk awal; (4) uji coba awal; (5) revisi produk;. Pada penelitian ini hanya sampai pada langkah kelima dari sepuluh langkah tersebut, karena keterbatasan, baik dari segi waktu maupun biaya. Teknik pengumpulan data menggunakan observasi, angket, wawancara, dokumentasi dan tes. Sedangkan teknik analisis data menggunakan analisis deskriptif kualitatif dan kuantitatif.

\section{HASIL DAN PEMBAHASAN}

Hasil observasi dengan siswa diperoleh data bahwa dalam pelajaran matematika pada masa pandemi sekarang ini dilakukan dengan memberi tugas saja tanpa ada penjelasan atau vidio pembelajaran yang membantu siswa untuk memahami materi pelajaran. Siswa kurang berminat dalam pelajaran matematika terutama faktorisasi prima karena siswa tidak paham hanya mempelajarai dari buku saja.

Hasil wawancara dengan 5 guru diperoleh bahwa guru dalam mengajar matematika secara daring hanya memberikan tugas saja. Guru jarang dan hampir tidak pernah mengajar dengan media pembelajaran daring.Sehingga siswa kurang berminat pada pelajaran matematika. Guru juga kesulitan dalam membuat media pembelajran karena kurangnya ketrampilan dan pengetahuan dalam pembuatan media pembelajaran secara daring. Pada akhirnya kurangnya minat siswa dalam pembelajaran matematika menyebabkan hasil belajar menjadi rendah. Oleh sebab itu perlu adanya media pembelajaran dalam pembelajaran daring yang berbasis android untuk meningkatkan hasil belajar siswa pada pelajaran matematika

Berdasarkan hasil responden guru dan siswa merupakan, respon positif menunjukkan persentase $90 \%$ dengan kategori sangat baik. Adapun hasil responden siswa menunjukkan persentase $89 \%$ dengan kategori sangat baik. Dari hasil persentase respon guru dan siswa menunjukan bahwa media pembelajaran 
matematika secara daring lebih mudah dipahami dengan menggunakan media pembelajaran berbasis android.

\begin{tabular}{lllc}
\hline No & \multicolumn{1}{c}{ Pertanyaan } & Ya & Tidak \\
\hline 1 & $\begin{array}{l}\text { Apakah dalam pembelajaran matematika secara } \\
\text { daring ini perlu media pembelajaran berbasis } \\
\text { android }\end{array}$ & 5 & 0 \\
\hline 2 & $\begin{array}{l}\text { Apakah bapak /Ibu guru pernah membuat media } \\
\text { pembelajaran untuk pembelajaran matematika }\end{array}$ & 4 & 1 \\
\hline 3 & $\begin{array}{l}\text { Apakah siswa lebih bersemangat dengan adanya } \\
\text { media pembelajaran berbasis dalam } \\
\text { pembelajaran matematika? }\end{array}$ & 0 \\
\hline 4 & $\begin{array}{l}\text { Menurut anda apakah media pembelajaran } \\
\text { berbasis android membantu anda dalam } \\
\text { pembelajaran daring ? }\end{array}$ & 5 & 0 \\
\hline 5 & $\begin{array}{l}\text { Apakah siswa lebih bersemangat dengan adanya } \\
\text { media pembelajaran faktorisasi prima dalam } \\
\text { pembelajaran matematika berbasis android? }\end{array}$ & 5 & 0 \\
\hline \multicolumn{4}{c}{ Jumlah respon positif } \\
\hline
\end{tabular}

Tabel 1 Hasil rekapitulasi respon guru terhadap Media Faktorisasi Prima

\begin{tabular}{lllc}
\hline No & \multicolumn{1}{c}{ Pertanyaan } & Ya & Tidak \\
\hline 1 & $\begin{array}{l}\text { Apakah dengan media pembelajaran kamu lebih } \\
\text { tertarik dengan pelajaran matematika? }\end{array}$ & 18 & 2 \\
\hline 2 & $\begin{array}{l}\text { Apakah media pembelajaran yang digunakan } \\
\text { guru bisa diakses di android? }\end{array}$ & 16 & 4 \\
\hline 3 & $\begin{array}{l}\text { Apakah kalian diajarkan cara menggunakan } \\
\text { media pembelajaran tersebut? }\end{array}$ & 20 & 0 \\
\hline 4 & $\begin{array}{l}\text { Apakah dengan menggunakan media media } \\
\text { pembelajaran kalian lebih mudah memahami soal } \\
\text { matematika? }\end{array}$ & 3 \\
\hline 5 & $\begin{array}{l}\text { Apakah dengan media pemebalajaran berbasis } \\
\text { android kalian lebih mudah mengerjakan soal } \\
\text { matematika? }\end{array}$ & 18 & 2 \\
\hline \multicolumn{4}{c}{ Jumlah respon positif } \\
\hline
\end{tabular}


Pengembangan Media Pembelajaran Faktorisasi Prima Berbasis Android diawali dari proses perencanaan, proses pengembangan dan evaluasi. Berdasarkan hasil observasidan wawancara, dapat diketahui bahwa media pembelajaran untuk pelajaran matematika materi faktorisasi prima sangat dibutuhkan.

Adapun model hipotetik yang dikembangkan adalah sebagaiberikut:

1. Perumusan Tujuan

Pada tahapan ini peneliti merumuskan tujuan penelitian yaitu pengembangan media pembelajaran faktorisasi prima berbasis android untuk meningkatkan pemahamansiswa tentang faktorisasi prima. Media pembelajaran faktorisasi prima berbasis android bertujuan untuk mempermudah siswa dalam memahami materi faktorisasi prima berupa media interaktif pembelajaran secara sederhana. Media pembelajaran faktorisasi prima berbasis android disertai beberapa latihan soal agar siswa lebih memahami materi yang dipelajari dan diaplikasikan dalam soal.

2. Menentukan Materi

Analisis materi akan disesuaikan dengan kebutuhan siswa tentang media pembelajaran dan disesuaikan dengan kompetensi dasar, indikator dan standar kompetensi serta tujuan pembelajaran materi faktorisasi prima kelas IV. Hal ini perlu untuk mengurangi ketidakefektifan pengembangan media pembelajaran.

3. Penentuan Media

Setelah dilakukan analisi materi langkah selanjutnya adalah menentukan media yang sesuai dengan materi yang dipilih. Hal ini dilakukan analisis kebutuhan dengan meakukan observasi, wawancara dan penyebaran angket terhadap guru dan siswa.

4. Menyusun Perangkat Pembelajaran

Pada tahapan ini sebelum melalukan penyusunan perangkat pembelajaran berupa RPP, silabus, program semester. Perangkat pembelajaran disusun untuk menyesuaikan dengan pengembangan media pembelajaran yang akan dibuat agar tujuan pengembangan bisa tercapai

5. Menyusun DesainMedia Pembelajaran Faktorisasi Prima 
Desain Pengembangan media pembelajaran faktorisasi prima berbasis android dibuat berdasarkan hasil respon siswa dan guru dan analisis kebutuhan media pembelajaran secara daring berbasis android. Diawali dengan menyiapkan perangkat lunak dalam pengembangan, membuat storyboard/desain gambar beserta dengan alur trigger/navigasi dari button yang di konsep dalam desain media pembelajaran serta menyiapkan media pendukung baik gambar, suara serta video.

6. Mengembangkan desain media pembelajaran

Konsep desain yang telah lengkap, dikembangkan menggunakan Articulatestoryline3 dan proses coding menggunakan software Web2 apk builder. Media pembelajaran hasil pengembangan telah diujicoba dipasang pada perangkat android dengan RAM 1GB dan OS 5.1.1 Lollipop. Media yang telah dikembangkan harus mendapatkan validasi dari ahli media dan ahli materi sebelum dilakukan uji lapangan. Hasil validasi oleh ahli materi memberikan nilai 3,82 dengan 23 indikator termasuk kriteria baik dengan sedikit catatan yaitu perlu menambah materi prasyarat. Sedangkan ahli media memberikan nilai 4,517 dengan kriteria sangat baik dengan catatan ukuran aplikasi yang masih besar agar dilakukan sedikit kompresi.

Gambar media pembelajaran faktorisasi prima berbasis android adalah sebagai berikut:

Ikon merupakan button / tombol utama untuk dapat masuk ke media pembelajaran faktorisasi prima berbasis android.

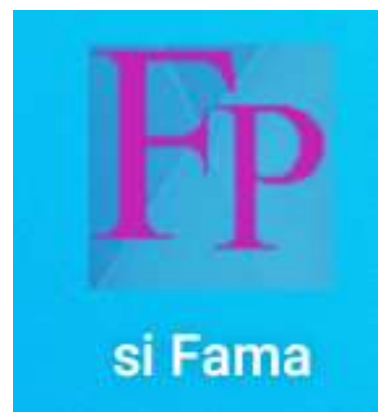

Gambar 1. Tampilan ikon media pembelajaran 
Menu utama terdiri atas 5 tombol yaitu Materi, Penjelas, Latihan, Ulangan dan Informasi. Menu utama diiringi dengan backsound.

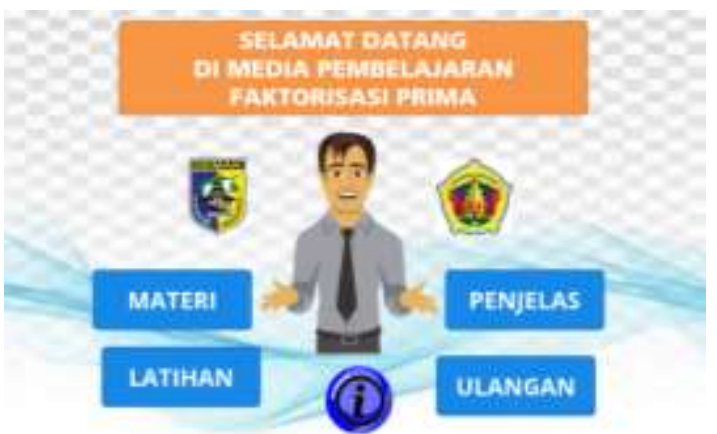

Gambar 2. Tampilan menu utama

Materi terdiri atas beberapa slide / tampilan yang berisi materi faktorisasi prima. Terdapat tombol navigasi untuk berpindah dari slide satu slide lainnya.

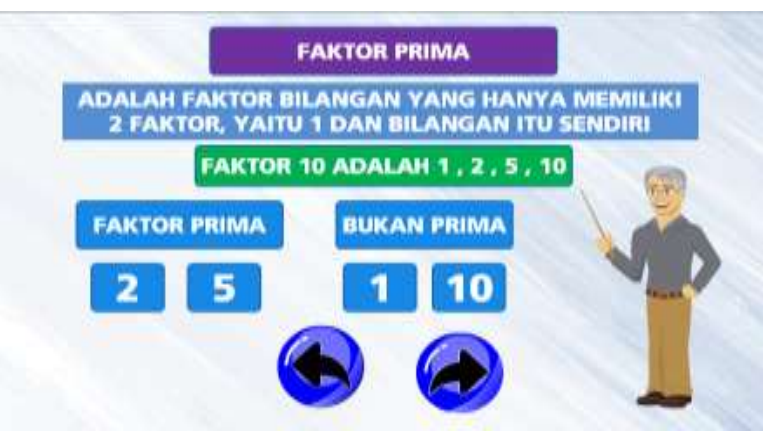

Gambar 3. Tampilan menu materi

Menu utama penjelas seperti gambar 4 berisi beberapa angka yang akan dijelaskan dan tombol navigasi menuju ke menu utama atau menu latihan. Gambar 5 merupakan contoh penjelas.

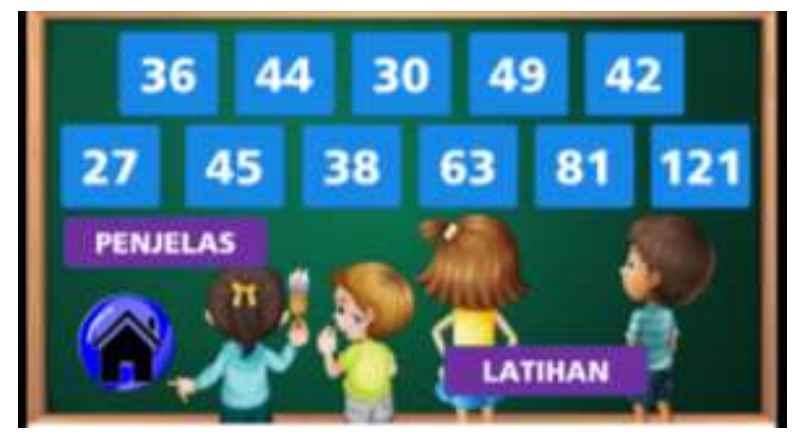

Gambar 4. Tampilan menu penjelas 


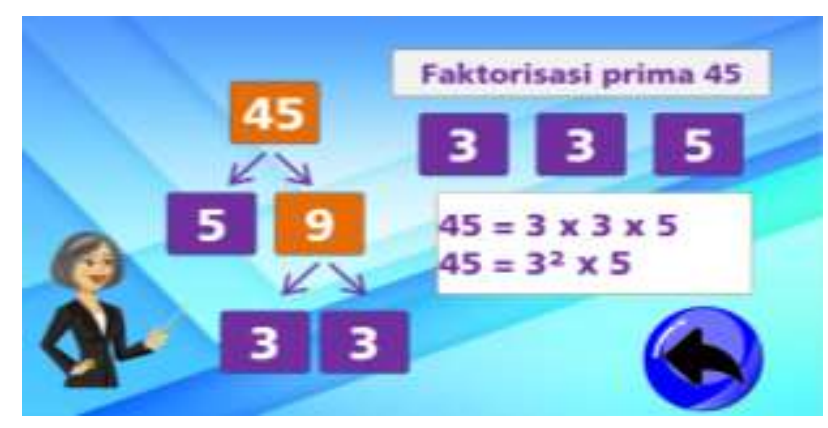

Gambar 5. Tampilan contoh penjelas

Menu utama latihan terdiri atas beberapa angka, tombol navigasi menuju game dan kembali ke menu utama. Latihan terdiri atas dua proses yaitu penyelesaian pohon faktor dan pilihan faktorisasi prima. Teknik yang digunakan adalah " $d r a g$ $n$ drop" dengan menekan dan menggeser pilihan jawaban ke tempat yang disediakan.

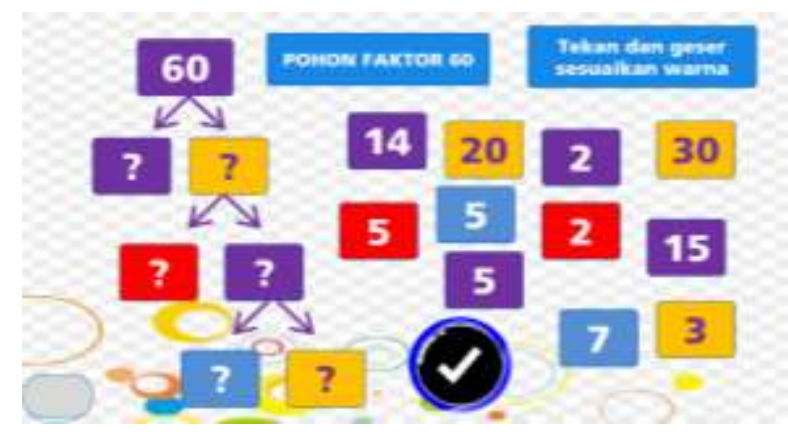

Gambar 6. Tampilan contoh latihan langkah 1

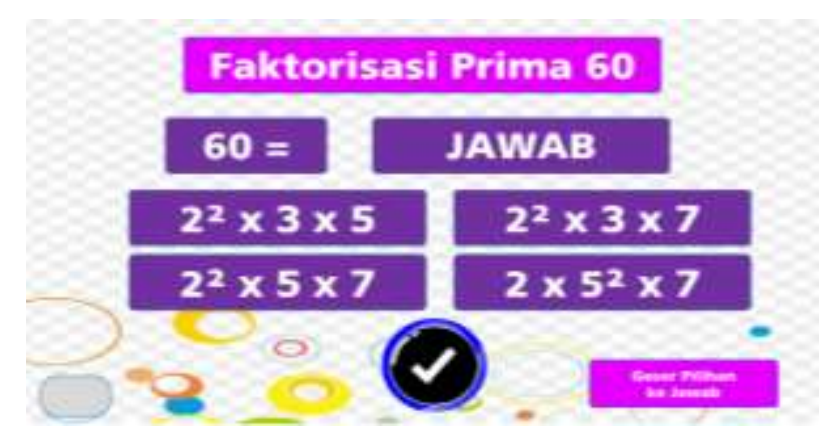

Gambar 7. Tampilan contoh latihan langkah 2

Jika pengguna memilih berlatih dengan menu Game, maka akan menuju ke permainan. Menu utama game gambar 8 terdiri atas 4 level, dan bukti pengguna menyelesaikan level akan sampai di reward gambar 10. Pengguna yang menyelesaikan soal dengan tepat akan menuju ke soal berikutnya, namun jika salah maka akan kembali ke awal level. 


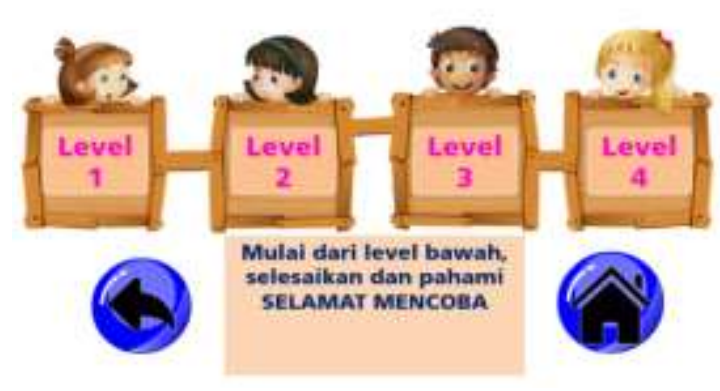

Gambar 8. Tampilan menu game

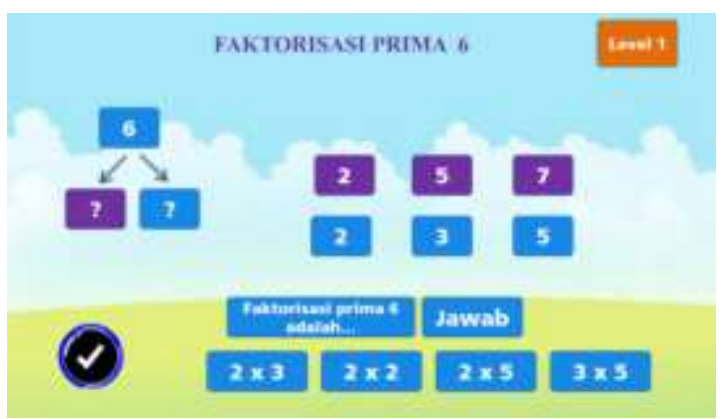

Gambar 9. Tampilan game

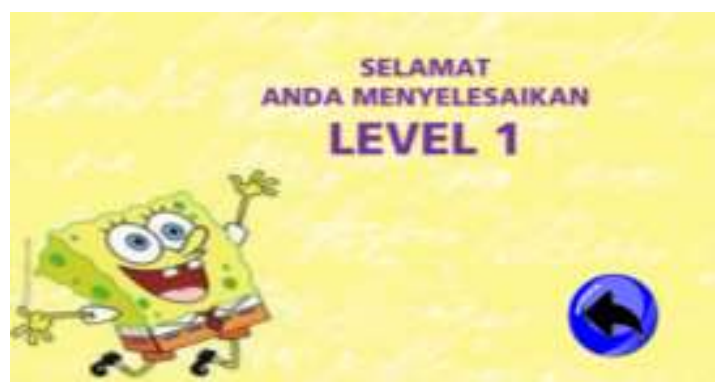

Gambar 10. Tampilan akhir game

Menu ulangan terdiri atas 10 soal pilihan ganda yang harus diselesaikan. Hasil perolehan pengguna akan keluar setelah penyelesaian soal. Review atas pekerjaan pengguna dapat dilakukan untuk mengetahui jawaban yang dipilih benar atau tidak. Menu informasi berisi tentang profil pengembang, media yang digunakan, sumber materi dan daftar pustaka. 


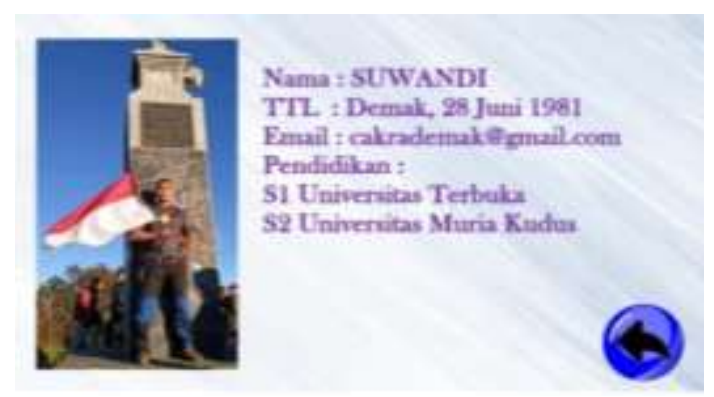

Gambar 11. Tampilan profil pengembang media

\section{KESIMPULAN}

Berdasarkan hasil penelitian pengembangan media pembelajaran faktorisasi prima berbasis android, dapat disimpulkan bahwa 1) Analisis kebutuhan guru dan siswa terhadap pengembangan media pembelajaran berbasis android dilakukan melalui observasi, wawancara, dan angket. Hasil analisis menunjukkan bahwa guru dan siswa membutuhkan adanya pengembangan media pembelajaran berbasis android untuk pembelajaran matematika materi faktorisasi prima, 2) Media pembelajaran berbasis androidyang dikembangkan berupa media pembelajaran faktorisasi prima berbasis android. Pengembangan media pembelajaran faktorisasi prima berbasis android digunakan dalam pembelajaran matematika materi faktorisasi prima pada siswa kelas IV Penggunaan media pembelajaran faktorisasi prima berbasis android ini digunakan untuk meningkatkan hasil belajar siswa kelas IVpada pelajaran matematika. Pengembangan media pembelajaran ini untukmenarik minat siswa dalam belajar matematika selama pembelajaran daring. Siswa akan lebih mudah dalam memahami materi pelajaran karena media pembelajaran faktorisasi prima berbasis android berupa visual dan gambar yaitu teks, gambar, suara dan video. Hasil validasi oleh ahli materi memberikan nilai 3,82 (layak) dengan 23 indikator termasuk kriteria baik dengan sedikit catatan yaitu perlu menambah materi prasyarat. Sedangkan ahli media memberikan nilai 4,517 dengan kriteria sangat baik dengan catatan ukuran aplikasi yang masih besar agar dilakukan sedikit kompresi. 


\section{DAFTAR PUSTAKA}

Arsyad, azhar. 2019. Media Pembelajaran. Jakarta; PT. Raja Grafindo Persada

Batubara, H. H. (2018). Pengembangan media pembelajaran matematika berbasis android untuk siswa SD/MI. Muallimuna: Jurnal Madrasah Ibtidaiyah, 3(1), 12-27. VOL. 3, NO. 1, OKTOBER, 2017. ISSN: 2476-970

Camacho, ACLF, Fuly, PSC, Santos, MLSC \& Menezes,HF . (2020). Students in social vulnerability in distance education disciplines in times of COVID-19. Research, Society and Development, 9(7):1-12, e275973979.

Dwanoko, Y. S. (2016). Implementasi Software Development Life Cycle (SDLC) Dalam Penerapan Pembangunan Aplikasi Perangkat Lunak. Jurnal Teknologi Informasi: Teori, Konsep, dan Implementasi, 7(2), 143003.

Fitriyani, Y., Fauzi, I., \& Sari, M. 2020. Motivasi Belajar Mahasiswa Pada Pembelajaran Daring Selama Pandemik Covid-19. Jurnal Kependidikan: Jurnal Hasil Penelitian dan Kajian Kepustakaan di Bidang Pendidikan, Pengajaran dan Pembelajaran, 6(2), 165-175. doi:https://doi.org/10.33394/jk.v6i2.2654

Gunawan, G., Harjono, A., Sahidu, H., \& Herayanti, L. (2017). Virtual laboratory to improve students' problem-solving skills on electricity concept. Jurnal Pendidikan IPA Indonesia, 6(2), 257-264.

Lee, Wei-Meng. (2011). Begining Android Application Development. Indianapolis:Wiley Publishing,Inc

Lidyawati, N., Pramita, S., Mardiani, M., \& Farisi, A. Aplikasi Pembelajaran Faktorisasi Prima Bilangan Bulat Positif dengan Pohon Faktor Berbasis Android. (http://eprints.mdp.ac.id/1367/

Nazarudin S.H. 2012. Pemograman Aplikasi Mobile Smartphone dan Tablet PC Berbasis Android. Informatika. Bandung

Nunuk, Setiawan, Aditin. 2018. Media Pembelajaran Inovatif dan Pengembangannya. Bandung: Remaja Rosdakarya.

Purwanto, A., Pramono, R., Asbari, M., Hyun, C. C., Wijayanti, L. M., \& Putri, R. S. (2020). Studi Eksploratif Dampak Pandemi COVID-19 Terhadap Proses Pembelajaran Online di Sekolah Dasar. EduPsyCouns: Journal of Education, Psychology and Counseling, 2(1), 1-12.

Rahmawati, R., \& Putri, E. M. I. (2020, June). Learning From Home dalam Perspektif Persepsi Mahasiswa Era Pandemi Covid-19. In Prosiding Seminar Nasional Hardiknas (Vol. 1, pp. 17-24).

Sanaky. 2015. Media Pembelajaran Interaktif-Inovatif. Yogyakarta: Kaukaba Dipantara. 
Sastra, R. (2017). Metode Pengembangan Perangkat Lunak Waterfall Dalam Perancangan Sistem Informasi E-Learning. IJSE-Indones. J. Softw. Eng. Metod, 3(1), 27-33.

Sugiyono.2016. Metode Penelitian Pendidikan pendekatan Kuantitatif, Kualitatif dan $R \& D$. Bandung: Alfabeta.

Sugiyono. 2019. Statistik untuk Penelitian. Bandung: Alfabeta

Zakiy, M. A., Syazali, M., \& Farida, F. (2018). Pengembangan Media Android dalam Pembelajaran Matematika. Triple $S$ (Journals of Mathematics Education), 1(2), 87-96. Vol.1 No.2 2018, 87-96 ISSN (E): 2622-4739 